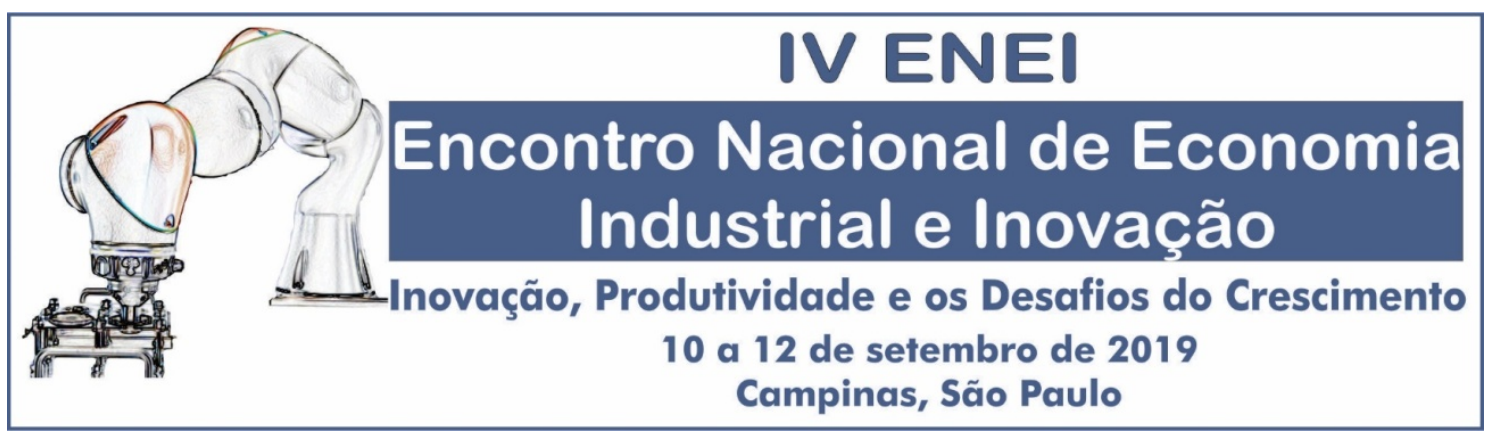

DESINDUSTRIALIZAÇÃO BRASILEIRA EM PERSPECTIVA: UMA ANÁLISE EMPÍRICA DO PROCESSO EM DIFERENTES NÍVEIS DE SEVERIDADE

Ednilson Silva Felipe Universidade Federal do Espirito Santo Arthur Colombo Universidade Federal do Espírito Santo Daniel Pereira Sampaio Universidade Federal do Espírito Santo 


\title{
DESINDUSTRIALIZAÇÃO BRASILEIRA EM PERSPECTIVA: UMA ANÁLISE EMPÍRICA DO PROCESSO EM DIFERENTES NÍVEIS DE SEVERIDADE
}

\begin{abstract}
Resumo
O objetivo deste artigo é analisar e investigar o processo de desindustrialização vivido pelo Brasil com uma proposta metodológica distinta das utilizadas usualmente. Através da proposta metodológica empírica, é possível inferir que a desindustrialização brasileira se apresenta como um processo complexo e ocorre em mais de um formato, sendo que esses formatos apresentam níveis de severidade distintos. Com a análise através de diversos indicadores sugeridos, a conclusão é de que o Brasil apresenta sinais de desindustrialização em pelo menos três formatos, que são: $i$ )desindustrialização relativa por aumento do gap tecnológico; ii) desindustrialização relativa por redução dos insumos nacionais pelos insumos importados; e iii) substituição do produto final nacional pelo produto importado.
\end{abstract}

Palavras-chave: Desindustrialização, Desindustrialização Relativa, Indústria de transformação brasileira

\begin{abstract}
The objective of this paper is to analyze the process of deindustrialization experienced by Brazilian industry with a different methodological proposal from those usually used. Through an empirical methodological propose, it is possible to infer that Brazilian deindustrialization is presented as a complex process and occurs in more than one format, and these formats have different levels of severity. With the analysis through several indicators, the conclusion is that Brazilian industry shows signs of deindustrialization in at least three formats: $\mathrm{i}$ - relative deindustrialization by increasing the technological gap; ii- relative deindustrialization by reduction of the national inputs; and iii - replacement of the national final product by the imported product.
\end{abstract}

Keywords: deindustrialization, relative deindustrialization formats, Brazilian manufacturing

JEL: L60

Área ABEIN

1.4 Padrões de especialização produtiva e desenvolvimento

\section{Introdução}

O objetivo neste artigo é analisar uma série de indicadores que demonstrem sinais da ocorrência do processo de desindustrialização no Brasil. Os indicadores mais tradicionais, não desconsiderando sua importância, apresentam algumas limitações e, devido a isso, serão trazidos indicadores que conformam várias propostas metodológicas de vários autores diferentes, todas de caráter mais empírico justamente buscando obter um maior poder de análise.

Esta proposta de junção de várias metodologias empíricas categoriza o processo de desindustrialização qualitativamente em duas formas distintas, de modo que esse processo pode ser verificado tanto no formato absoluto quanto no relativo. O absoluto é o grau mais severo no qual a desindustrialização pode ser encontrada, mas não será objeto deste trabalho. Neste formato, as unidades industriais encerram suas atividades, ou seja, ocorre o fechamento de unidades industriais. A outra maneira (ou formato) no qual o processo pode ser constatado é a relativa, sendo que esta pode ser dividida em três maneiras distintas: i) desindustrialização relativa por aumento do gap tecnológico; ii) desindustrialização relativa por redução do conteúdo nacional pelo conteúdo importado e iii) substituição do produto final nacional pelo produto importado (HIRATUKA E SARTI, 2017; SAMPAIO, 2015; DINIZ, 2017; MORCEIRO, 2018).

Esses três formatos de desindustrialização relativa estão exatamente colocados em ordem crescente de severidade, ou seja, do menos intenso (causa menores consequências) ao mais intenso (causa maiores consequências), de maneira que para cada formato desses existem indicadores que permitem denotar se existe alguma evidência de sua presença de fato ou não. A seguir, cada seção deste artigo trará 
de maneira mais detalhada qual é a definição de cada um desses formatos assim como os indicadores que auxiliam na busca por indícios do processo, objetivando buscar possíveis sinais de desindustrialização relativa. ${ }^{1}$

\section{DESINDUSTRIALIZAÇÃO RELATIVA POR AUMENTO DO GAP TECNOLÓGICO}

O primeiro formato proposto a ser investigado é a desindustrialização relativa por aumento do gap tecnológico. O objetivo é investigar se existe um aumento da discrepância entre a tecnologia usada pelo setor industrial brasileiro em relação ao mesmo setor dos países desenvolvidos, ou seja, observar se ao longo dos anos a indústria de transformação brasileira apresentou algum sinal de obsolescência quando comparada aos seus concorrentes no cenário internacional. Caso isso se mostre verdadeiro, o gap tecnológico pode ser apontado como uma das possíveis causas para a desindustrialização já que, neste caso, a perda de competitividade pelo atraso tecnológico diminui os espaços para a indústria brasileira.

A partir dos anos de 1980, a indústria nacional brasileira apresentou dificuldades em incorporar os avanços tecnológicos alcançados pelas nações desenvolvidas. Isso denota defasagem tecnológica de décadas, causando perda de competitividade da indústria brasileira. Um método possível para averiguar essa defasagem é através da observação histórica de como o Brasil se engaja como nação subdesenvolvida e, por isso, ingressa de maneira subordinada no que se refere à competição internacional, como, por exemplo, através das cadeias globais de valor. As inovações tecnológicas que proporcionam as técnicas mais modernas de produção e, por consequência, maior competitividade, na grande maioria das vezes surgem com pioneirismo nas economias desenvolvidas, principalmente em setores de maior intensidade tecnológica e a partir disso, se inicia uma corrida das demais nações para a incorporação dos novos moldes de produção.

Hiratuka e Sarti (2017) demonstram que nas últimas décadas aconteceram significativas mudanças na concorrência mundial do setor manufatureiro e, a partir disso, os países líderes desta disputa industrial se dividiram em dois grupos. O primeiro é composto por países desenvolvidos que deixaram de lado a preocupação em verticalizar toda a produção ao longo da cadeia produtiva $\mathrm{e}$ passaram a dar ênfase a uma estrutura mais flexível. O principal objetivo era permanecer no controle de ativos intangíveis e externalizar atividades de menor intensidade tecnológica. Com isso é possível notar que o grande objetivo desses países é manter internalizados os elos da cadeia produtiva que são produtores e difusores de novas tecnologias.

O outro grupo de países é composto principalmente pelas economias asiáticas que absorveram a maioria dos elos expurgados pelas nações desenvolvidas e contemplaram um projeto industrial baseado em baixos custos de mão de obra, elevada escala, câmbio competitivo e potentes incentivos governamentais. Na Tabela 1 podemos observar os dados de aplicação de patentes por continente. Os dados foram obtidos a partir do relatório do World Intellectual Property Organization (WIPO)de 2018:

Tabela 1: Aplicação de Patentes por Continente (\%)

\begin{tabular}{c|c|c|c}
\hline Região & $\mathbf{2 0 0 7}$ & $\mathbf{2 0 1 7}$ & Variação (p.p.) \\
\hline Ásia & 49,7 & 65,1 & 15,4 \\
\hline América do Norte & 26,4 & 20,3 & $-6,1$ \\
\hline Europa & 18,1 & 11,2 & $-6,9$ \\
\hline América Latina & 3,1 & 1,8 & $-1,3$ \\
\hline Oceania & 1,9 & 1,1 & $-0,8$ \\
\hline África & 0,8 & 0,5 & $-0,3$ \\
\hline
\end{tabular}

Fonte: GURRY, 2018, p. 26

Em 2007 já era notório uma acentuada diferença na aplicação de patentes entre a América Latina e outros continentes como América do Norte e Europa, que representavam 26,4\% e 18,1\%,

\footnotetext{
${ }^{1}$ Pela falta de dados conclusivos sobre a desindustrialização do tipo absoluta, a análise deste artigo ficará restrita ao estudo da desindustrialização do tipo relativa.
} 
respectivamente. $\mathrm{O}$ continente latino americano representava apenas 3,1\%. Em 2017 a história não se altera de maneira drástica, mas todos os continentes (com exceção da Ásia) apresentam uma queda no indicador. A única diferença fica por conta da Ásia que passou de 49,7\% em 2007 para 65,1\% em 2017, boa parte como resultado das políticas de inovação chinesa que absorveu parte significativa dos Investimentos Externos Diretos de origem nos países desenvolvidos ${ }^{2}$. Este resultado sugere a presença de um intenso gap tecnológico entre a América Latina e as principais nações desenvolvidas. Portanto, é notório que a política realizada por estes países acaba mantendo e até mesmo intensificando o distanciamento tecnológico existente entre eles e as nações em desenvolvimento como o Brasil.

Cassiolato, Szapiro e Lastres (2015) avaliam os resultados das políticas brasileiras de incentivo à inovação que se iniciam a partir de 2003. Originalmente, um dos objetivos era justamente diminuir o gap tecnológico das unidades produtivas brasileiras. Porém, a análise dos autores constatou que os resultados se mostraram muito aquém do esperado. Tabela 2 traz indicadores obtidos através da pesquisa de inovação (PINTEC), referentes a inovação na indústria de transformação no período de (1998-2014):

Tabela 2: Taxa de Inovação do Setor Manufatureiro Brasileiro em \% (1998-2014)

\begin{tabular}{c|c|c|c|c|c}
\hline Período & $\begin{array}{c}\text { Taxa de } \\
\text { Inovação }\end{array}$ & $\begin{array}{c}\text { Taxa de } \\
\text { Inovação de } \\
\text { Produto }\end{array}$ & $\begin{array}{c}\text { Taxa de Inovação de } \\
\text { Produto Novo para o } \\
\text { Mercado Nacional }\end{array}$ & $\begin{array}{c}\text { Taxa de } \\
\text { Inovação de } \\
\text { Processo }\end{array}$ & $\begin{array}{c}\text { Taxa de Inovação de } \\
\text { Processo Novo para o } \\
\text { Mercado Nacional }\end{array}$ \\
\hline $1998-2000$ & 31,52 & 17,58 & 4,13 & 25,22 & 2,78 \\
\hline $2001-2003$ & 33,27 & 20,35 & 2,73 & 26,89 & 1,21 \\
\hline $2003-2005$ & 33,36 & 19,53 & 3,25 & 26,91 & 1,66 \\
\hline $2006-2008$ & 38,11 & 22,85 & 4,10 & 32,10 & 2,32 \\
\hline $2009-2011$ & 35,56 & 17,26 & 3,66 & 31,67 & 2,12 \\
\hline $2012-2014$ & 36,30 & 18,30 & 3,80 & 32,70 & 2,60 \\
\hline
\end{tabular}

Fonte: CASSIOLATO; SZAPIRO; LASTRES, 2015 p. 390. Elaboração própria com base na PINTEC/IBGE

Embora a taxa de inovação, de maneira geral, tenha se elevado, é possível notar que Taxa de Inovação de Produto Novo para o Mercado Nacional, que se refere a um produto introduzido pela primeira vez na economia brasileira e Taxa de Inovação de Processo Novo para o Mercado Nacional, que se refere a processos introduzidos pela primeira vez na economia brasileira, apresentaram uma evolução decrescente de 4,13\% no período $1998-2000$ para 3,80\% no período $2012-2014$ e 2,78\% para 2,12\% respectivamente no mesmo período. Não obstante, a taxa de inovação de produto teve aumento de maneira relativa até 2008 , porém, despencou no subperíodo seguinte se apresentando em $17,26 \%$ tendo leve recuperação para $18,3 \%$ no período $2012-2014$.

Isso pode ser explicado devido a estratégia utilizada e apoiada pelo governo para melhorar o desempenho em relação à inovação. $O$ apoio preferencial das unidades industriais foi em relação à compra de máquinas e equipamentos, de maneira que $27,27 \%$ utilizaram preferencialmente esse incentivo e 74\% das unidades consideram que este é um apoio de alta ou média importância. Portanto, é notório que boa parte da estratégia para inovação das empresas está embasada em uma estratégia que pode ser considerada passiva, o que acaba trazendo apenas pequenas melhorias com impactos irrisórios na estrutura produtiva (CASSIOLATO; SZAPIRO; LASTRES, 2015).

A política brasileira caracteriza-se pela promoção de institucionalidades "ofertistas", como incubadoras, cidades inovadoras, núcleos de inovação tecnológica, redes de inovação, plataformas tecnológicas, com resultados questionáveis. Evidentemente há um aspecto extremamente positivo no sentido de que elas contribuem significativamente para as capacitações tecnológicas. Mas seu impacto na estrutura produtiva tem sido muito pequeno e praticamente todas elas dependem do apoio público para sobreviver...Alguns dos principais problemas dessas propostas ofertistas em países como o Brasil é exatamente a falta de uma demanda pelo setor produtivo e a inexistência de

\footnotetext{
${ }^{2}$ Para maiores detalhes sobre o avanço Asiático ver Diniz, (2017).
} 
Seguindo com a análise de indicadores, para mais uma proxy da magnitude do gap tecnológico do Brasil em relação aos outros países, serão apresentados a seguir alguns dados trazidos pelo estudo Global Index Inovation (GII) ${ }^{3}$. Elaborado desde 2007, o estudo conta hoje com 127 países representando por volta de $92 \%$ da população, em torno de $98 \%$ do PIB mundial e traz indicadores elaborados, além dos indicadores que envolvem apenas artigos científicos publicados ou nível de investimentos em pesquisa e desenvolvimento de cada país (DUTTA; LANVIN, 2018). A Tabela 3 traz a evolução do desempenho geral no Brasil a partir de 2011²:

Tabela 3: Evolução do ranking do Brasil no GII

\begin{tabular}{c|c}
\hline Anos & Posição no Ranking \\
\hline 2011 & 47 \\
\hline 2012 & 58 \\
\hline 2013 & 64 \\
\hline 2014 & 61 \\
\hline 2015 & 70 \\
\hline 2016 & 69 \\
\hline 2017 & 69 \\
\hline \multicolumn{2}{|c|}{ Fonte: DUTTA; LANVIN, 2018, p. 14. Elaboração própria }
\end{tabular}

Através da Tabela 3 é constatada a evolução negativa do Brasil. Em 2011 o país aparecia na 49a posição, porém perdeu posições com o passar dos anos e, em 2017, se encontrava $69^{\mathrm{a}}$ colocação. É interessante lembrar que é a segunda pior colocação brasileira desde a criação deste indicador. Para entender como esse ranking é determinado, o esquema a seguir ilustrará os pontos que são levados em consideração pelo GII:

Figura 1: Sumário do GII, seus subíndices e indicadores

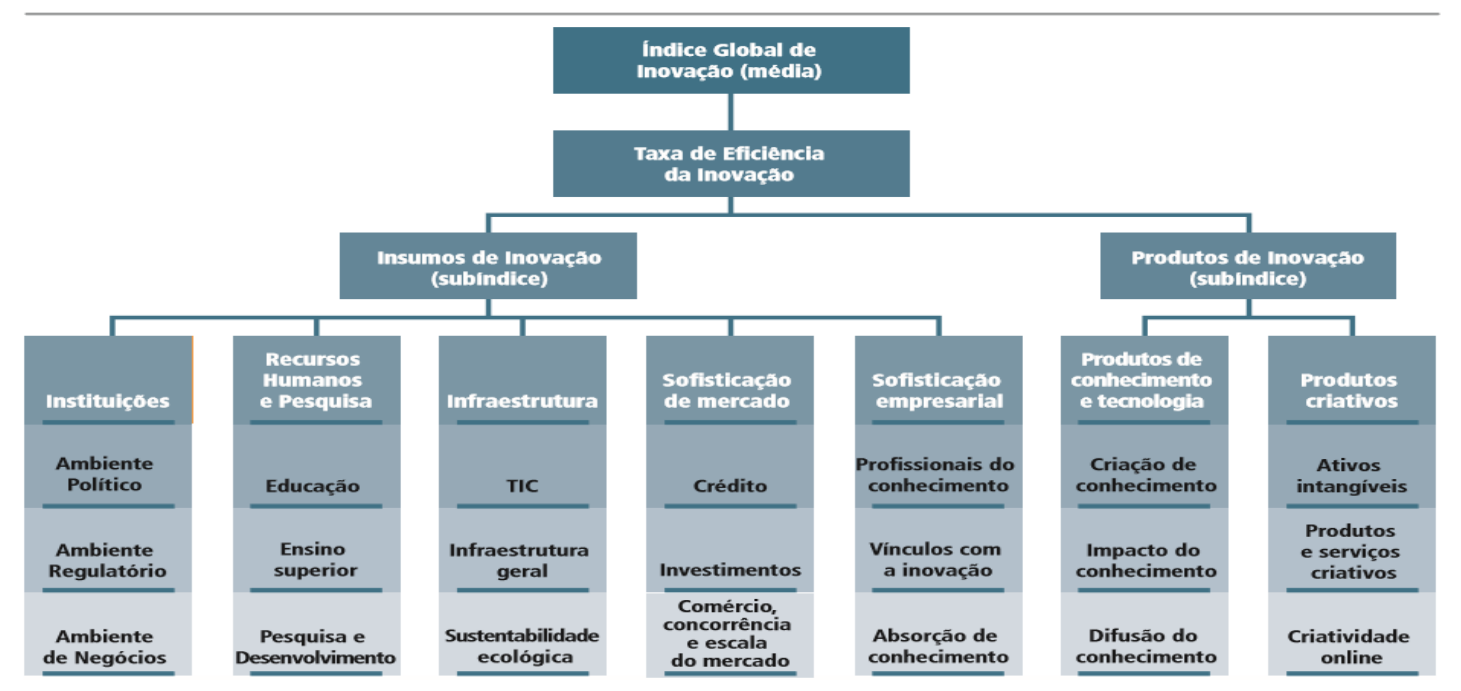

Fonte: DUTTA; LANVIN, 2018, p.13

\footnotetext{
${ }^{3} \mathrm{O}$ estudo do GII foi idealizado por Soumitra Dutta, da Universidade de Cornell, e o relatório foi produzido por ele em coautoria com Bruno Lanvin, da INSEAD, e Sacha Wunsch-Vincent, da Organização Mundial da Propriedade Intelectual (OMPI, ou WIPO, do inglês World Intellectual Property Organization).

${ }^{4}$ Embora o estudo seja realizado desde 2007 os formuladores do estudo alertaram que os primeiros dados poderiam apresentar muitos ruídos como em qualquer pesquisa em seu início por isso o GII, 2017 traz os dados a partir de 2011.
} 
Como podemos perceber através da Figura 1, o ranking tem como objetivo principal medir a taxa de eficiência da inovação. Este ranking é elaborado levando em consideração dois fatores: insumos de inovação e produtos de inovação. Cada um desses fatores dá origem aos 7 pilares utilizados como referência pelo GII de maneira que insumos de inovação são compostos por: $i$ ) Instituições; ii) recursos humanos; iii) infraestrutura; iv) sofisticação de mercado e v) sofisticação empresarial. Já produtos de inovação são compostos por: $i$ ) produtos de conhecimento e tecnologia e ii) produtos criativos, formando assim os 7 pilares levados em consideração pelo GII. Na Figura 2 está a comparação através desses pilares entre o Brasil e as nações consideradas mais inovadoras em 2017:

Figura 2: Comparação do Brasil com EUA, Suécia, Suíça, Reino Unido e Holanda

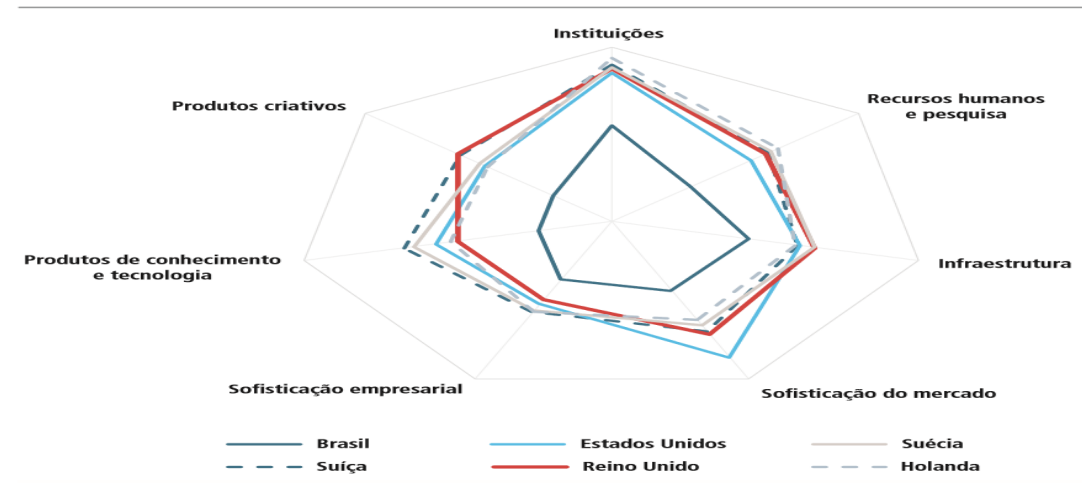

Fonte: Elaboração própria através dos dados do GII

Como é visível, existe uma diferença no mínimo discrepante entre a pontuação brasileira e todas as outras nações que se apresentam nas melhores classificações que são respectivamente: $1 .^{\circ}$ Suíça, $2{ }^{\circ}$ Suécia, 3. ${ }^{\circ}$ Holanda, $4 .^{\circ}$ Estados Unidos e 5. ${ }^{\circ}$ Reino Unido. Para alcançar um patamar próximo ao da Suíça, o Brasil deveria aumentar em no mínimo $60 \%$ sua capacidade referente a insumos de inovação e em cerca de 190\% sua capacidade referente a produtos de inovação, as demais nações inovadoras revezam entre si o protagonismo nos demais pilares com destaque para os EUA que se sobressai de maneira excepcional no pilar sofisticação do mercado (DUTTA; LANVIN, 2018). O estudo possibilita a comparação entre o Brasil e outras nações em estágios de desenvolvimento semelhante, trazendo os dados embasados nos 7 pilares de China, Rússia, Índia e África do Sul, como pode ser observado na Figura 3:

Figura 3: Comparação do Brasil e os Outros integrantes do BRICS:

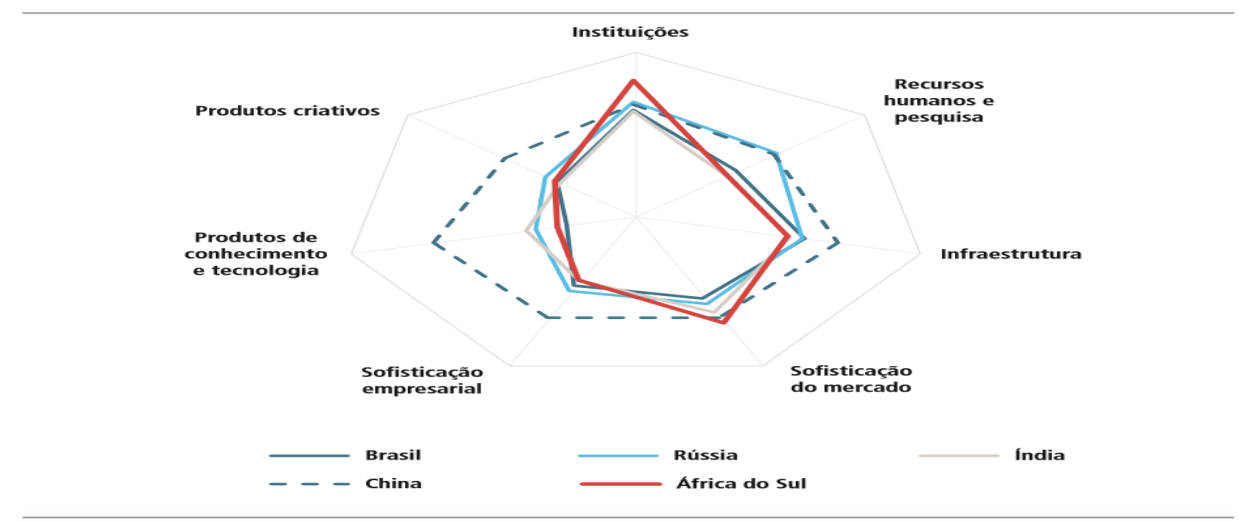

Fonte: Elaboração própria através dos dados do GII

Como é observado, o desempenho chinês é superior aos demais integrantes dos BRICS, e mesmo quando a comparação é feita entre estes países, o Brasil não se encontra em uma posição de protagonismo, o que indicada dificuldade do país em acompanhar as reorganizações e alterações 
produtivas mundiais. É importante também analisar a evolução ao longo dos anos (2011-2017). Enquanto África do Sul, Rússia, China e Índia ganharam posição no ranking do GII $(+2,+11,+7$ e +2 posições $)$ respectivamente, o Brasil perde posições (-22 posições). Esses dados demonstram que o Brasil não tem somente um desempenho fraco quando comparado às nações de vanguarda, mas também tem o pior desempenho entre os emergentes levando em consideração este levantamento.

A fim de investigar outros métodos e indicadores que permitem mensurar (mesmo que de maneira relativa) o gap tecnológico que o Brasil possivelmente vem acumulando ao longo dos anos, podemos observar outros trabalhos que tem como finalidade contribuir com esta discussão.

Arend e Fonseca (2012) têm um objetivo semelhante, o que permite utilizar os resultados obtidos como uma proxy para mensurar um possível gap tecnológico. Os autores incorporam em sua análise aspectos da escola neoschumpeteriana: a evolução ao longo dos anos ocorre fundamentalmente através de revoluções tecnológicas. Essas revoluções trazem inúmeras alterações nas estruturas produtivas. Os países que se apresentam na vanguarda dos novos padrões tecnológicos geralmente tomam a liderança do desenvolvimento no cenário global. Esta tomada de liderança em novas dinâmicas de produção é denominada de forging ahead. A partir disso, é natural que outras nações tenham como objetivo principal ingressar nesta nova dinâmica produtiva ocasionada pelo último salto tecnológico. Assim, o sucesso neste emparelhamento é denominado de catching up enquanto o insucesso é chamado de falling behind. Para verificar o sucesso ou insucesso neste emparelhamento ao longo dos anos, os autores escolheram o método histórico-analítico proposto por Perez (2004) que pode ser resumido pelo esquema a seguir:

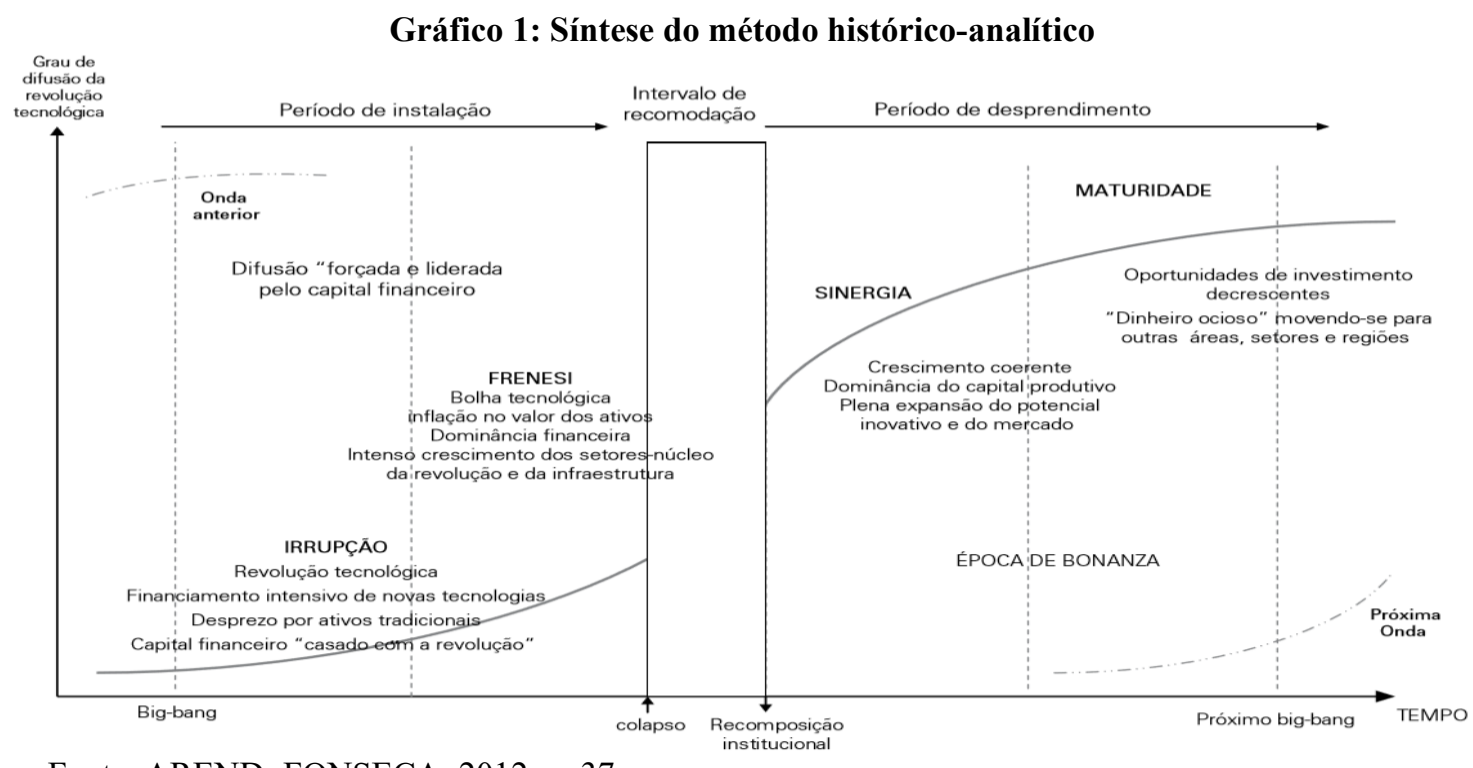

Fonte: AREND; FONSECA, 2012, p. 37

Como explicam os autores, cada revolução faz com que posteriormente ocorram períodos específicos:

O primeiro período, denominado de instalação, corresponde aos primeiros 20-30 anos iniciais do paradigma tecnoeconômico. As duas ou três décadas seguintes correspondem ao período denominado de desprendimento (ou dispersão), caracterizado pela disseminação completa da revolução tecnológica. Todavia, cada um desses períodos é subdividido em duas fases: a primeira fase do período de instalação é denominada de "irrupção"; e a segunda, de "frenesi". As fases do período de desprendimento são respectivamente denominadas de "sinergia" e "maturidade". Fundamental também é perceber que ao redor da metade de uma revolução tecnológica, depois do período de instalação e antes do período de desprendimento, há um interregno denominado pela autora de "intervalo de reacomodação", cuja periodicidade varia em cada revolução, podendo ser de poucos anos até uma década ou mais (AREND; FONSECA, 2012, p. 36).

Os autores concluem que o Brasil conseguiu, de maneira relativa, um emparelhamento tecnológico com as nações de vanguarda no período de 1955-1980, porém, este sucesso no catching up brasileiro foi baseado nas "idas e vindas" do capital estrangeiro e não em um processo autônomo de superação do 
atraso por parte das unidades industriais locais. O sucesso advindo dessas "idas e vindas" do capital estrangeiro além de arriscadas e incertas, não garantem a endogeinização técnica, o que se mostrou como uma falha grave justamente porque a partir dos anos 1980 os fluxos de capital assumiram uma postura demasiadamente financeira desvinculando-se da economia real, de maneira que a estratégia brasileira baseada em um desenvolvimento internacionalista acarretou um padrão de baixo dinamismo no longo prazo, transferindo a nação para uma situação de falling behind (AREND; FONSECA, 2012).

Oreiro, Basilio e Souza (2013) argumentam de uma maneira relativamente distinta das conclusões apresentadas até aqui. Os autores concluem que o Brasil incumbe em falling behind por administrar a taxa de câmbio de maneira equivocada. Segundo a estimativa dos autores, elaborada através de uma série de modelos econométricos distintos, a taxa de câmbio real efetiva no período compreendido entre 1996-2007 permaneceu em um patamar de $48 \%$ mais apreciada do que um patamar que permitisse competitividade à indústria, portanto para que o país tivesse sucesso no emparelhamento tecnológico o fator principal seria uma acentuada desvalorização cambial.

A partir da literatura demonstrada durante esta seção foi possível constatar que mesmo utilizando métodos, referenciais teóricos e indicadores diferentes, a conclusão da grande maioria dos trabalhos é sempre direcionada para a presença de um gap tecnológico elevado do Brasil em relação a outras nações. O gap tecnológico sem dúvida é um fator importante que explica a perda de dinamismo e consequentemente de competitividade da indústria brasileira.

Alguns fatores podem explicar o porquê de uma série de indicadores apontarem para esta situação de atraso tecnológico, que, como consequência, traz a desindustrialização por aumento de gap tecnológico. Pode-se ressaltar, por exemplo, a argumentação de Oreiro (2016) para quem existe uma grande importância de manter o câmbio em um nível que proporcione competitividade para a indústria: se ao longo dos anos o câmbio permanece distante deste patamar, o estímulo para investimento fica restrito, justamente porque este tipo de investimento demanda recursos em uma escala elevada e se a lucratividade do setor se apresenta esmagada devido ao câmbio sobrevalorizado, uma possível maturação do investimento se torna mais tardia, o que pode acabar desestimulando este tipo de investimento.

A partir dos indicadores acima indicados, fica razoavelmente claro que a partir da década de 1980 e de maneira mais intensa recentemente (principalmente após a crise de 2008) o gap tecnológico não somente existe, como foi aprofundado, trazendo significativa perda de competitividade da indústria brasileira devido ao distanciamento tecnológico. Os motivos passam desde "paradoxo" de políticas do governo que não parecem estar em ressonância com um mesmo objetivo e também a falta de investimento em pesquisa por parte do empresariado, que não o faz devido a uma série de fatores. Para exemplificar podemos citar sua lucratividade esmagada ao longo dos anos, mais recentemente devido ao alto endividamento e o esvaziamento dos incentivos devido a recente crise fiscal vivida pelo país.

\section{DESINDUSTRIALIZAÇÃO RELATIVA POR REDUÇÃO DO CONTEÚDO NACIONAL E AUMENTO DO IMPORTADO}

Nesta seção será apresentado o segundo formato de desindustrialização relativa apresentado na proposta metodológica dos autores mencionados na introdução: a desindustrialização relativa por redução do conteúdo nacional pelo aumento do conteúdo importado. É importante ressaltar que neste formato, o processo é mais grave e suas consequências são mais severas para a indústria de transformação. Neste formato, parte dos insumos que outrora eram de origem nacionais, perdem espaço para os importados, provocando uma ruptura dentro das cadeias produtivas nacionais, ou seja, o produto final passa a ter vários componentes que foram obtidos via mercado externo. Por isso, o processo também pode ser chamado de desindustrialização relativa por quebra de elos em cadeias produtivas (SAMPAIO, 2015; DINIZ, 2017).

Um dos indicadores que pode ser utilizado como proxy para denotara presença deste formato do processo no Brasil é o coeficiente de insumos importados da indústria de transformação. Este é um indicador construído pela Confederação Nacional da Indústria (CNI), que mensura a participação dos insumos importados no total de insumos utilizados pelo setor na produção de um bem. O Gráfico 2 demonstra a evolução desse indicador no período compreendido entre 2003-2017 a preços: 
Gráfico 2: Coeficiente de Insumos Importados da Indústria de Transformação (Preços Constantes\%)

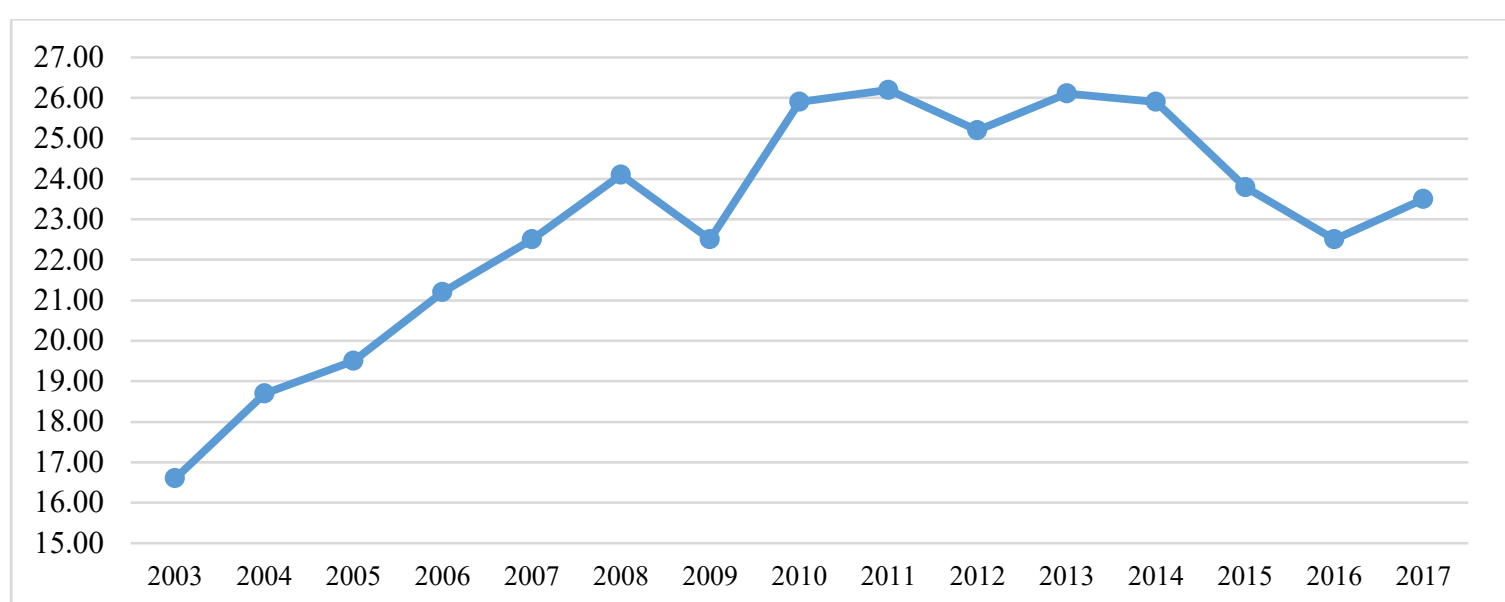

Fonte: CNI, Vários anos. Elaboração própria

Observando a evolução descrita no Gráfico 2, é possível intuir que a indústria nacional passou a ter um aumento da dependência do setor externo para realizar a produção. Em 2003, por volta de 16,6\% dos insumos eram obtidos via importações. Já em 2011 é possível identificar o maior valor presente nesta série, cerca de $26,2 \%$ dos insumos da indústria de transformação passam a ser importados, um aumento significativo de aproximadamente 10 p.p. Posteriormente o indicador demonstra ligeira queda apresentando-se na casa dos $23,5 \%$, porém, observando a série como um todo fica clara o aumento da dependência de bens intermediários estrangeiros para a produção industrial.

Ao retomar os argumentos de autores da linha de pensamento ortodoxo, é possível verificar que a abertura comercial é, na grande maioria das vezes, encarada como benéfica. Através dela a indústria brasileira poderia ter acesso aos melhores bens e fatores de produção como capital, tecnologia e trabalho, proporcionando uma alocação eficiente dos recursos e assim a indústria nacional ascenderia a um maior nível de produtividade e competitividade. Desta forma, aumentar a quantidade de insumos importados teoricamente não seria algo prejudicial para a manufatura nacional.

A despeito desta teoria, existem diversos indícios de que a abertura comercial brasileira trouxe como consequência uma especialização regressiva da estrutura industrial nacional ${ }^{5}$. A própria evolução demonstrada no Gráfico 2 já se mostra como um primeiro indício deste movimento, denotando que a indústria nacional passou a externalizar parte importante da produção industrial. Para entender a transformação pela qual passou a indústria nacional, é necessário analisar primeiramente os fatores externos que forçaram este movimento. É possível observar que nas últimas décadas (especialmente a partir dos anos de 1990) houve um forte processo de internacionalização tanto financeira quanto produtiva e, a partir disso, procurando aumentar a competitividade, uma parcela considerável da indústria residente nos países desenvolvidos decidiu delegar parte da produção suas filiais em países em desenvolvimento, buscando menores custos salariais, institucionais e até mesmo ambientais, ou seja, ocorreu uma desverticalização produtiva planejada ${ }^{6}$ (HIRATUKA; SARTI, 2017).

A grande maioria desses investimentos produtivos externalizados se destinou aos países asiáticos, em especial à China, deixando países como o Brasil em segundo plano. A partir desse movimento de forte inserção do mercado chinês na produção de manufatura, percebe-se que isto acarretou uma forte queda nos preços de bens industriais, levando a competição a níveis diferenciados de outrora. A competição de manufaturados passou a se apresentar em uma nova modalidade, marcada principalmente pelos preços

\footnotetext{
${ }^{5}$ Especialização regressiva da estrutura industrial nacional será tratado aqui como um sinônimo de quebra de elos ao longo das cadeias produtivas. Esse termo foi utilizado pela primeira vez em Coutinho (1997).

${ }^{6}$ Como já mencionado na seção anterior, o setor manufatureiro originado nos países desenvolvidos optou por concentrar nacionalmente estágios da produção que reservam maiores capacidades possibilidades de inovação assim como capitais intangíveis.
} 
mais baixos. Este movimento, impactando diretamente na rentabilidade, forçou algumas empresas a optar por insumos importados ao invés de novos investimentos na produção de insumos (LAVOPA; SZIRMAI, 2015; CASSIOLATO; LASTRES, 2015).

Ao observar os dados da demanda agregada nacional ${ }^{7}$ é possível perceber que o Brasil teve resultados positivos de 2001 até 2014, porém a indústria nacional não obteve o mesmo êxito, mantendose relativamente estagnada entre 2001 e 2013 e posteriormente caindo em abrupta recessão. Uma possível análise é de que o processo de quebra de elos está diretamente ligado a isso. O aumento da demanda nacional por bens manufaturados provocou uma transferência de boa parte da produção para o exterior, movimento esse acentuado a partir da crise de 2008, configurando um aprofundamento da especialização regressiva da estrutura industrial (DINIZ, 2017).

Sarti e Hiratuka (2017) utilizam a comparação entre a evolução do produto industrial e os principais componentes da demanda agregada para auxiliar a análise. O Gráfico 3 abaixo mostra a evolução de variáveis como produto manufatureiro, PIB, consumo, gasto público, investimento, importação e exportação no período entre 2001-2016.

Observando o Gráfico, é possível notar que todas as variáveis tiveram trajetória ascendente até a eclosão da crise internacional em 2008. A partir de 2006 é possível observar uma forte alta das importações, o que de início não se mostrou um problema, porque correspondeu a um período de grande alta das exportações que em sua grande maioria foi puxada por um forte aumento de preços das commodities. Além disso, até a eclosão da crise internacional em 2008 a produção manufatureira acompanhou o crescimento do PIB assim como das demais variáveis como consumo, investimento e gasto público. Porém, a partir de 2009 o produto manufatureiro manteve-se relativamente estagnado crescendo a um patamar inferior a essas variáveis.

Gráfico 3: Evolução do produto manufatureiro, PIB, gasto público, consumo, importação e exportação (base média $2000=100)$

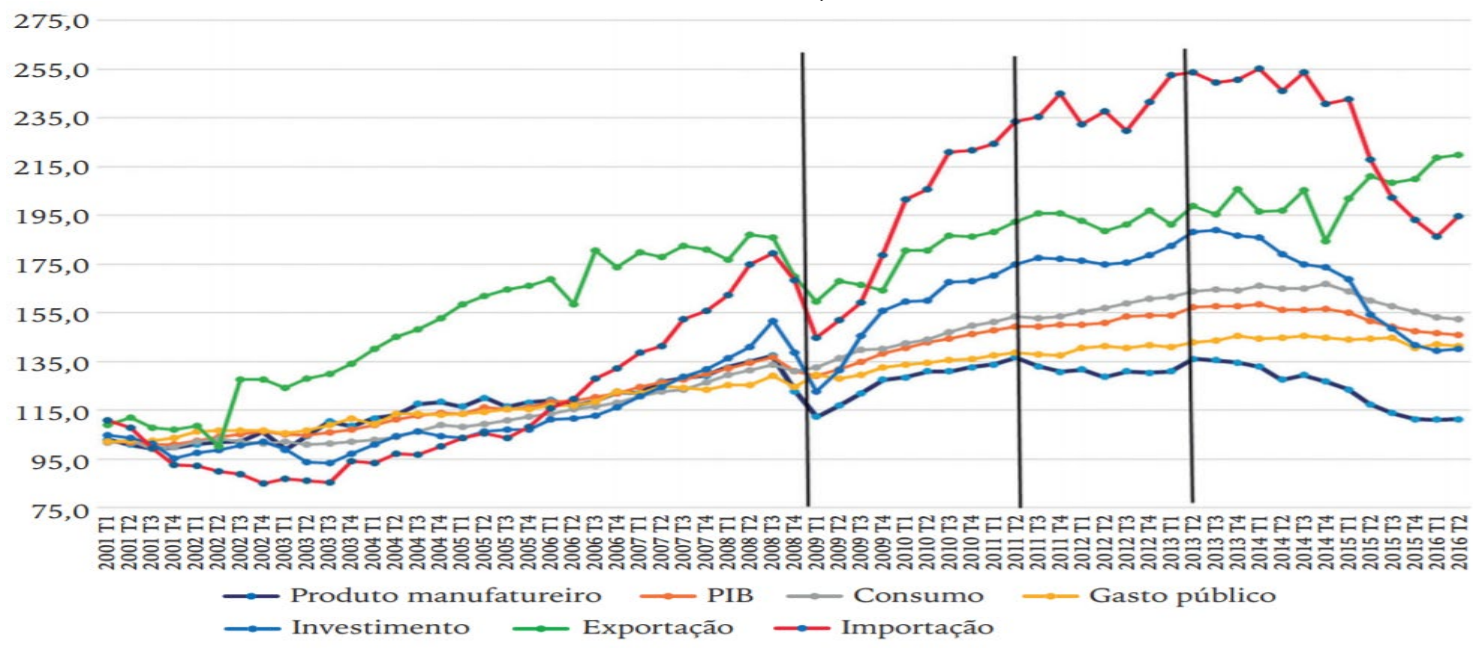

Fonte: SARTI; HIRATUKA, 2017, p. 13

O grande motivo para isso é que durante todo o período demonstrado no gráfico acima, especialmente a partir da grande crise, a indústria nacional passou a delegar parte da produção ao exterior, ou seja, substituiu a produção interna optando pelas importações. Isso em parte pode ser explicado pelo aumento de insumos importados como já foi demonstrado no Gráfico 2 e também ao aumento do coeficiente de penetração de importações ${ }^{8}$. Outro resultado que reforça a ideia trazida pelos autores é o saldo da balança comercial de manufaturados, no qual é possível observar um forte aumento das importações principalmente a parir de 2009, fazendo com que o resultado obtido fosse negativo. Esta

\footnotetext{
${ }^{7}$ Ver Gráfico 3.

${ }^{8}$ Embora Sarti e Hiratuka, (2017) utilizem tanto o coeficiente de insumos importados, quanto o coeficiente de penetração das importações para indicar o processo de especialização regressiva da estrutura produtiva, o indicador de coeficiente de penetração das importações será trazido e analisado na próxima seção, na qual o processo indicado será o terceiro tipo de desindustrialização relativa.
} 
evolução do indicador reforça a ideia de que boa parte desse aumento das importações deve-se ao aumento das importações de manufaturados como pode ser observado no Gráfico 4 a seguir:

Gráfico 4: Saldo da Balança Comercial de Produtos Manufaturados 1995-2016 (US\$ Bilhões)

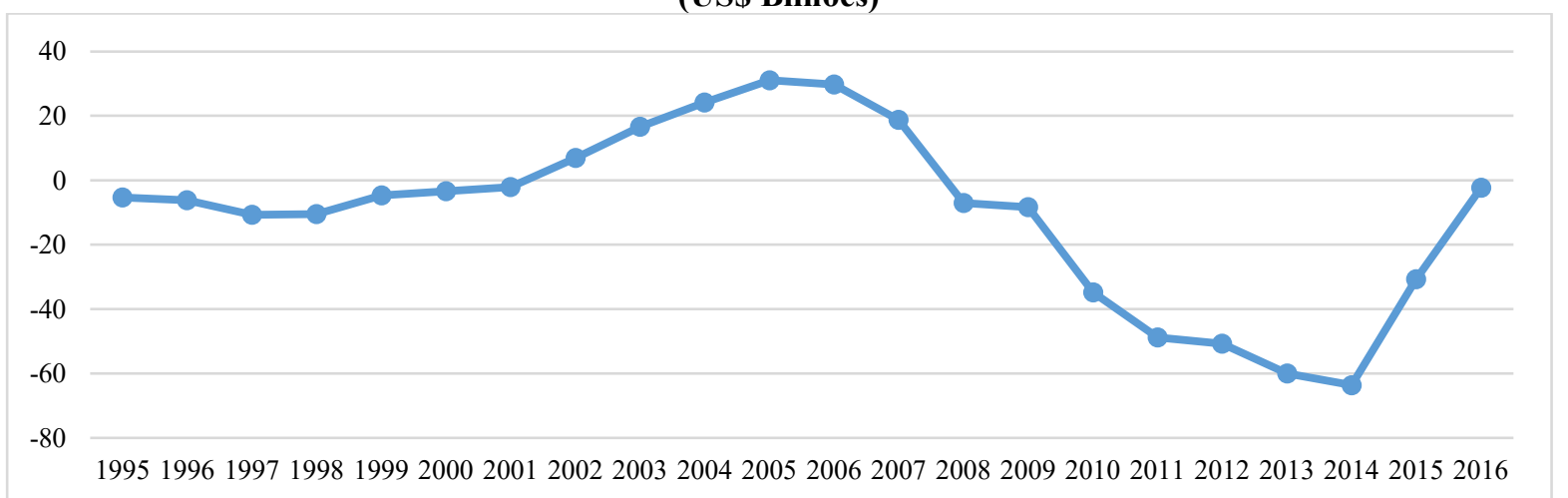

Fonte: IEDI (2017). Elaboração própria

Como é notório, após a crise o valor da balança comercial de manufaturados passou a atingir um nível fortemente deficitário, se intensificando até 2014 quando atingiu o seu nível mais elevado sugerindo que a indústria de transformação nacional adotou uma espécie de estratégia defensiva. Portanto, como sugerem os autores, o desempenho pífio do produto industrial (principalmente após 2009) não foi devido a uma situação de insuficiência de demanda interna, mas sim por um forte vazamento ao exterior. Outro movimento que não pode ser marginalizado da análise é o que se iniciou em 2014. Se de 2011 a 2014 a evolução do produto industrial pode ser classificada como fraca, depois disso pode ser classificado como em queda livre, como demonstrado no Gráfico 3 através do variável produto manufatureiro. Além do vazamento externo observa-se a retração do consumo em conjunto com uma abrupta queda dos investimentos, o que intensificou o movimento negativo da indústria nacional ${ }^{9}$ (SARTI; HIRATUKA, 2017).

Segundo Morceiro (2018), os resultados negativos sobre o segmento de bens intermediários podem aparecer de duas maneiras distintas. A primeira é diminuição das demandas inter e intra-setorial. A diminuição da demanda inter-setorial acarreta em uma diminuição na produção de bens de consumo duráveis, não duráveis e bens de capital. Já a queda intra-setorial acaba ocorrendo pela própria diminuição da demanda de bens intermediários o que causa uma diminuição da demanda por insumos industriais. Já a segunda maneira em que resultados negativos sobre o segmento de bens intermediários podem aparecer é quando estes produtos (bens intermediários) em um primeiro momento são produzidos internamente, porém a demanda de boa parte passa a ser atendida pelo exterior, ou seja, através de importações dos insumos.

\begin{abstract}
Depois do início da crise internacional, como visto, as importações se aceleraram, enquanto o produto industrial se estagnou (2011-2013) e depois declinou (2014-2016). O impacto do aumento das importações e da redução das demandas inter e intra-setoriais levaram a uma contração expressiva de $13,5 \%$ da produção de bens intermediários no período $2013-2016 \ldots{ }^{10}$ o aumento das importações de insumos industriais afetou negativamente a produção doméstica desses produtos. Dado o peso do segmento na estrutura industrial como um todo, isso contribuiu para desacelerar e depois reduzir o produto industrial (SARTI; HIRATUKA, 2017, pp. 16-20).
\end{abstract}

\footnotetext{
${ }^{9} \mathrm{Nem}$ mesmo a queda nas importações e a leve recuperação das exportações industriais em 2015 alteraram a trajetória de queda do produto industrial (SARTI; HIRATUKA, 2017).

${ }^{10}$ Os autores também enfatizam que a queda mais que proporcional da indústria de transformação de 2014 a 2016 , é explicada também pelos desempenhos negativos dos segmentos de bens de capital e de bens de consumo duráveis (SARTI E

HIRATUKA, 2017).
} 
Gráfico 5: Evolução do produto industrial da indústria de transformação e de bens intermediários (base média de 2012 =100)

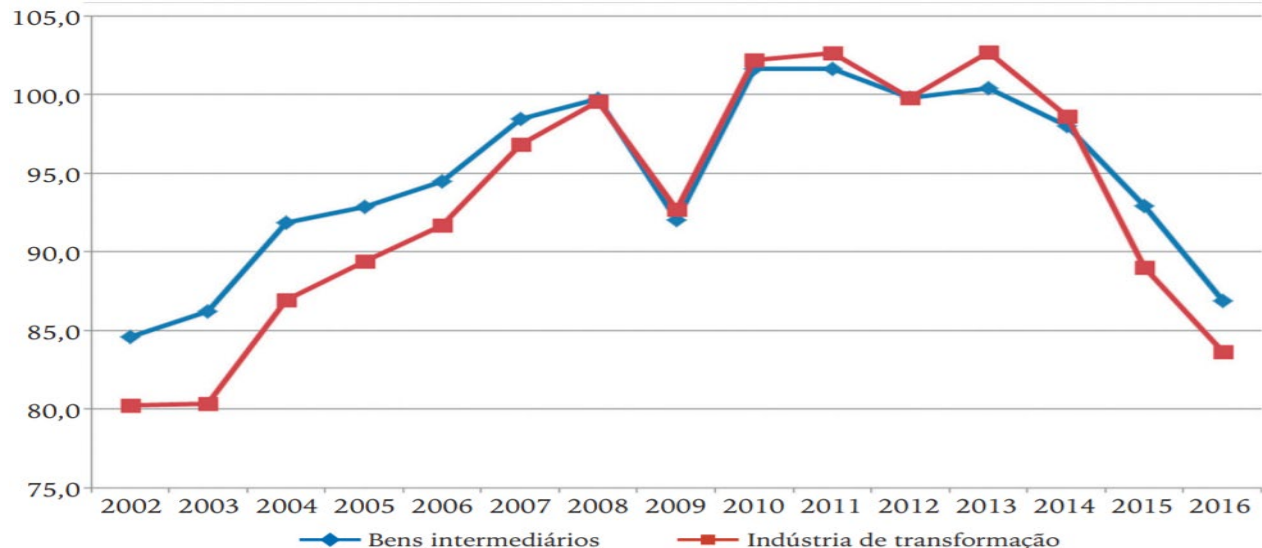

Fonte: IBGE, Vários anos. Elaboração Neit/IE/Unicamp

Como foi enfatizado pelos autores, o movimento de especialização regressiva da estrutura produtiva industrial nacional traz consigo consequências negativas para a produção industrial. Uma nova rodada de abertura comercial, por exemplo, pode intensificar ainda mais este processo, tornando a indústria nacional cada vez mais dependente de importações e como consequência direta agregar cada vez menos valor com a produção:

O resultado do processo de desnacionalização foi o aprofundamento da especialização regressiva da estrutura produtiva e de exportação acompanhada da elevação do conteúdo e coeficiente importados, sem a contrapartida de um aumento proporcional do coeficiente exportado manufatureiro e o que é pior, dos investimentos industriais. Nesse sentido, o Brasil apresenta um padrão assimétrico e subordinado de inserção externa (SARTI; HIRATUKA, 2017, p. 28).

Portanto através dos dados apresentados, houve uma mudança de caráter estrutural da indústria brasileira nas últimas décadas, aumentando o uso de insumos importados; ao invés de melhora o que foi constatado foi uma acentuada perda de competitividade, ou seja, a perda de parte do tecido industrial está diretamente ligada com a significativa desnacionalização da estrutura produtiva brasileira (CASSIOLATO; SZAPIRO; LASTRES, 2015).

É possível encontrar mais um indicador que auxilia na investigação de uma possível presença de desindustrialização relativa por quebra de elos, a relação VTI (Valor da Transformação Industrial) / VBPI (Valor Bruta da Produção Industrial) ${ }^{11}$ da indústria de transformação. O VBPI expressa o valor total das vendas de produtos industriais fabricados e serviços industriais prestados pela indústria de transformação, ajustado pela variação de estoques; já o VTI, é o resultado da diferença entre o VBPI e os Custos das Operações Industriais (COI). O COI corresponde ao valor dos custos diretamente envolvidos na produção, tais como matérias-primas utilizadas, consumo de energia elétrica, combustíveis, dentre outros (TORRES; CAVALIERI, 2015). Este indicador geralmente é utilizado para análises de cunho mais específico como as regionais, ou seja, os estudos são feitos procurando observar a evolução deste indicador nos Estados de maneira individual.

Ao investigar a literatura que tem como objetivo analisar a relação VTI/VBPI da indústria de transformação, é possível observar que em muitos casos essa relação é utilizada para mensurar a densidade das cadeias produtivas, ${ }^{12}$ na medida em que valores maiores (próximos de 1) significa um maior adensamento nas cadeias produtivas e valores menores (próximos de 0) significa um menor

\footnotetext{
${ }^{11}$ VTI: Valor da Transformação Industrial (reflete a soma daquilo que cada etapa da produção (cadeia produtiva) agregou (adicionou) ao produto ao longo do processo de produção).

VBPI: Valor Bruta da Produção Industrial (é a soma das vendas de produtos e serviços industriais receita líquida industrial + a variação de estoques de produtos acabados e em elaboração + a produção própria realizada para o ativo permanente). Toda a análise assim como o cálculo do indicador VTI/VBPI (neste artigo) se refere a indústria de transformação (DIEESE 2011).

${ }^{12}$ Uma queda na relação VTI/VBPI ao longo dos anos significando em um menor adensamento das cadeias produtivas é o que possível serve como proxy para a existência ou não de desindustrialização relativa por quebra de elos.
} 
adensamento ao longo das cadeias produtivas. A procura em quantificar o adensamento das cadeias produtivas é fundamental como observam Torres e Cavalieri (2015):

\begin{abstract}
A avaliação da densidade das cadeias produtivas industriais mostra-se como uma questão central no que diz respeito ao diagnóstico da desindustrialização. A densidade expressa a capacidade da indústria em agregar valor à produção a partir da distribuição dos diferentes estágios produtivos por elos que compõem a cadeia de produção. À medida que atividades antes realizadas em solo nacional são substituídas por importações, segmentos da estrutura produtiva são perdidos e, junto com eles, os respectivos postos de trabalho e valores adicionados. Assim, esse processo tem como resultado a ampliação do coeficiente importado de insumos industriais e o enfraquecimento dos efeitos multiplicadores do produto (TORRES; CAVALIERI, 2015, p. 867).
\end{abstract}

A despeito de críticas que existem a esse indicador ${ }^{13}$, o Gráfico 6 descreve a evolução deste indicador, no período entre 1996-2016 ${ }^{14}$. Mesmo com suas limitações, vários trabalhos importantes com relação ao tema da desindustrialização utilizaram este indicador e até mesmo a condução de políticas industriais, como, por exemplo, o Plano Brasil Maior (2011) no qual havia parte de seus objetivos atrelados ao valor desta relação, deste modo sua análise não deve ser expurgada por completo:

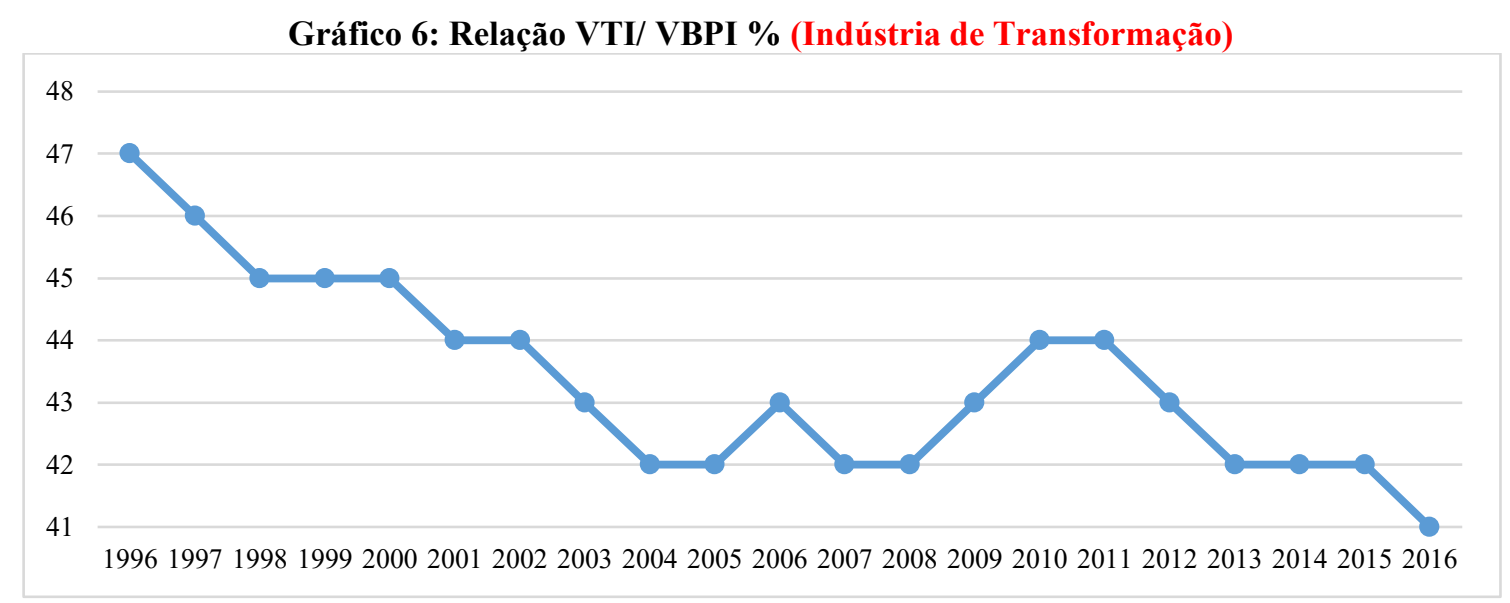

Fonte: (PIA/IBGE), Vários anos. Elaboração Própria.

Partindo do Gráfico 6, percebe-se uma queda na relação VTI/VBPI da indústria de transformação ao longo dos anos. Em 1996 o valor encontrado era de 47\%, já em 2016 de 41\%. Entre 2008 e 2011 houve uma leve recuperação de $42 \%$ para $44 \%$, porém, logo depois o indicador mostrou nova queda, terminando a série em 2016 com o valor de 41\%. Como mencionado acima, o Plano Brasil Maior, que foi lançado em agosto de 2011 e revisado no início de 2012, tinha como um de seus objetivos aumentar o adensamento produtivo nacional, alcançando até 2014 um valor de 45,3\% (TORRES; CAVALIERI, 2015).

A evolução dos dados indica um menor adensamento das cadeias produtivas na indústria de transformação brasileira, ou seja, uma fragilização da estrutura industrial nacional. Esta evolução denota que a capacidade de agregar valor da indústria de transformação brasileira apresenta sinais de deterioração, seguindo a mesma conclusão do indicador anterior e demonstrando o aumento da

\footnotetext{
${ }^{13}$ A crítica é que esta relação é fortemente influenciada por variações no câmbio, de maneira que em um determinado setor que é dependente de insumos importados para a produção, uma possível valorização cambial pode acarretar em uma diminuição do COI, ou seja, os custos de produção ficam menores consequentemente aumentando o VTI. Com o numerador maior (ceteris paribus) é provável que a relação VTI/VBPI aumente seu valor, indicando um adensamento maior nas cadeias produtivas, justamente o contrário do que realmente está acontecendo na realidade, ou seja, as unidades industriais vão comprar mais insumos no exterior ao invés dos nacionais, portanto a relação não só não consegue captar esta diminuição no adensamento das cadeias produtivas como também acaba levando a um raciocínio oposto do que realmente está ocorrendo devido à sua alta sensibilidade a variações cambiais (TORRES; CAVALIERI, 2015).

${ }^{14}$ Este período foi escolhido, porque a partir de 1996, ocorreu uma mudança no método de cálculo utilizado pela PIA/IBGE, portanto os dados dos anos anteriores não seriam úteis para a análise.
} 
necessidade de importar de insumos, peças e outros componentes, em detrimento dos distribuidores locais, portanto, corroborando com a existência de um possível processo de desindustrialização relativa por diminuição do conteúdo nacional pelo importado (quebra de elos).

Segundo Cano (2014), a relação VTI/VBPI da indústria de transformação segue esta trajetória principalmente devido à ausência de políticas industriais robustas e de desenvolvimento da conjugação de juros elevados, falta de investimento, câmbio demasiadamente sobrevalorizado e intensa e desregrada abertura comercial.

A verdadeira "avalanche" de importações, principalmente quanto aos bens de consumo duráveis, deu-se graças ao dólar barato e à abertura comercial mal negociada. Esse aumento de importações vem, em parte, quebrando ou debilitando elos de várias cadeias produtivas e, assim, eliminando empresas e linhas produtivas de várias empresas. Ao mesmo tempo, o fenômeno é altamente inibitório do investimento normal e daquele típico inovador ou mesmo o que complementa cadeias produtivas. Há de se entender que eliminar uma empresa é relativamente fácil, em tais circunstâncias. Destruir uma liderança industrial nacional, um empresário industrial dinâmico, como ocorreu com vários, também é fácil. O difícil é criar ou tentar recriar tais empresas e respectivas lideranças. (CANO, 2014, p. 27)

Segundo Diegues e Rossi (2017), a onda liberalizante ocorrida no Brasil a partir dos anos de 1990 embalada nas ideias do consenso de Washington como intensa abertura comercial e financeira, sem o devido planejamento e cuidado com seus desdobramentos para com a indústria nacional em conjunto com uma política de juros altos e câmbio sobrevalorizado levaram a indústria nacional a reagir a este cenário adverso. Esta reação da indústria acabou possuindo caráter defensivo, dando origem a um novo padrão de organização que segundo os autores pode ser resumido em um tripé:

(i) reorganização das unidades produtivas locais, adequando-as aos novos condicionantes competitivos das redes globais de produção e viabilizando assim a integração essencialmente importadora nessas redes;

(ii) aumento do mercado interno, fomentado pela distribuição de renda, aumento da massa salarial, do emprego e do crédito e

(iii) acoplamento do parque produtivo doméstico ao mercado internacional como grande ofertante de produtos intensivos em recursos naturais (DIEGUES; ROSSI, 2017, pp. 16-17).

Essas transformações embasadas nestes pontos deram origem ao que os autores denominaram de doença brasileira, que seria o novo padrão de organização e acumulação da indústria nacional. Este novo padrão reconfigurou estruturalmente a indústria nacional que caminhou para uma especialização regressiva ou, usando o termo da metodologia aqui proposta, incumbiu em quebra de elos ao longo das cadeias produtivas. Portanto a doença brasileira nada mais é do que a reafirmação através de uma nova nomenclatura, de toda a ideia expressada anteriormente nesta seção, de maneira que ela é a transferência de parte da produção que outrora era nacional para o exterior, como um dos meio encontrados pela indústria nacional para manter sua rentabilidade frente a um cenário externo extremamente competitivo $\mathrm{e}$ um interno com variáveis sistêmicas desajustadas:

[...] a indústria brasileira conseguiu se adaptar e reconfigurar suas atividades produtivas, reduzindo gradativamente o conteúdo local adicionado a sua produção. Essa redução, por sua vez, foi acompanhada do crescimento da importação de produtos finais, partes, peças e componentes a partir da integração importadora das nas cadeias produtivas globais. Deste modo, observou-se o surgimento de uma indústria doméstica com uma dinâmica competitiva e de acumulação completamente distinta daquela vigente nos países asiáticos que conseguiram engendrar uma inserção externa virtuosa através da exportação de manufaturados (DIEGUES; ROSSI, 2017, p. 18).

Portanto, o cenário marcado pela doença brasileira reduz drasticamente a capacidade da indústria de transformação ser a catalisadora de um processo de crescimento associado à diversificação e às transformações estruturais fundamentadas no incremento e na disseminação da produtividade intersetorial nos moldes sugeridos por Kaldor (DIEGUES; ROSSI, 2017). 
Como ressalta Ricúpero (2014), mesmo depois que a instabilidade dos preços foi atingida com o Plano Real, abertura comercial e financeira na década de 1990, o nível de investimento na indústria nunca mais retornou aos patamares que eram observados antes da crise dos anos de 1980. Essa análise do autor em conjunto com dados apresentados nesta seção possibilita a apresentação de uma conclusão que a economia brasileira apresenta sinais do que o autor chama de "primeiro estágio"15 de desindustrialização.

Mesmo não sendo considerado o mais danoso dentre todas as possibilidades, este formato de desindustrialização relativa já apresenta sérias consequências. A obtenção de insumos via importação acarreta em uma diminuição de renda e empregos que seriam gerados no Brasil. Ambos passam a ser delegados a outras nações e, além disso, se restringe a possibilidade do surgimento de novos progressos técnicos devido à impossibilidade de acesso da produção ao longo de toda a cadeia produtiva (CARNEIRO, 2008). A presença de desindustrialização relativa por quebra de elos retira boa parte das vantagens que provém da indústria de transformação em relação aos outros setores. A indústria de transformação fica marcada pela desconcentração produtiva, aproximando-se do modelo industrial mexicano, conhecido na literatura como "maquiladoras".

Ricúpero (2014) atenta ao fato de que a proximidade geográfica e comercial com os EUA aumenta a adesão desta forma de produção industrial, o que não é ideal, pois nestes moldes de produção industrial não é possível tornar o comércio através da indústria de transformação o "motor de crescimento" para o país devido ao baixo valor agregado gerado com a produção. Neste modelo, a tendência é que as unidades industriais se alojem em regiões, onde a mão de obra e impostos são mais atrativos, gerando migrações e concentrações.

Marconi e Rocha (2012) elaboraram um estudo econométrico e constataram que existe uma correlação inversa entre a participação de insumos importados e o valor adicionado da indústria de transformação no Brasil, ou seja, quanto maior for a dependência de importação de insumos para a produção, menor será a agregação de valor através na produção industrial.

A Comissão Econômica para a América Latina e o Caribe - Cepal (2008) realizou um estudo similar, porém para a economia Mexicana e os resultados obtidos caminharam na mesma direção concluindo que quanto maior a necessidade de importar insumos ao longo dos anos, menor será a possibilidade da atividade industrial agregar valor. Tais resultados vão na contramão de algumas instituições que pregam uma abertura comercial mais ampla como a Organização para a Cooperação e Desenvolvimento Económico (OCDE). Em entrevista à Carta Capital, Sarti e Lacerda (2018) afirmam que o modelo de maquiladoras enfraquece não apenas a indústria nacional e seu valor gerado, mas o país como um todo acaba sentindo essas consequências:

\begin{abstract}
Em outras palavras, a desnacionalização galopante de hoje "transfere para fora do Brasil decisões de onde realizar os investimentos, quanto e o que produzir e exportar para quais mercados. Quando se abdica de manter no País os centros de decisão das empresas, é claro que a base produtiva fica muito enfraquecida" ...A indústria é absolutamente chave, dadas as conexões com os demais setores e por ser potencialmente a maior geradora de valor agregado, ou seja, de emprego, renda, pagamento de impostos. Uma crise nunca se circunscreve a ela, mas atinge toda a economia com aumento do desemprego, precarização do trabalho e da renda, perda de tecnologia, desmantelamento das cadeias produtivas, substituídas na maioria das vezes por importados (SARTI; LACERDA, 2018, não paginado).
\end{abstract}

Ou seja, segundo os autores, delegar tais decisões ao setor externo pode privar não apenas decisões e o desenvolvimento da indústria nacional, mas também limita a elaboração de um projeto nacional de desenvolvimento. Através desta seção foi possível notar que uma variada gama de autores heterodoxos, de maneira relativa, converge a um mesmo diagnóstico; Embora os trabalhos utilizem indicadores e até mesmo métodos distintos, existe uma espécie de consenso de que a indústria nacional após as medidas da década de 1990 passou a ter uma estratégia distinta da observada até então e se tornou

\footnotetext{
${ }^{15}$ Para Ricúpero (2010), a quebra de elos é considerada o primeiro estágio de desindustrialização, porém na metodologia proposta aqui, a quebra de elos não representa especificamente um estágio, justamente porque ela pode ocorrer ao mesmo tempo das outras categorias, não necessariamente precisa ocorrer uma depois a outra. É possível que esteja ocorrendo mais de uma categoria ao mesmo tempo.
} 
mais dependente de componentes, peças e insumos estrangeiros para a produção, o que configura a presença de sinais uma possível desindustrialização por quebra de elos.

\section{DESINDUSTRIALIZAÇÃO RELATIVA POR SUBSTITUIÇÃO DO PRODUTO FINAL NACIONAL PELO IMPORTADO}

Prosseguindo com a investigação através da metodologia proposta, outra categoria de desindustrialização relativa é a Substituição do Produto Nacional Final pelo produto Importado, sendo que dentro do conjunto do tipo relativo esta é a mais grave. Nesta categoria, o produto final não é mais nem sequer montado no Brasil, ele é obtido diretamente pronto via importação, ou seja, toda a produção de um determinado bem fica delegada à indústria externa, com isso a indústria nacional não tem a possibilidade de ter acesso a nenhum (ou quase nenhum) estágio de produção de determinado bem. Não é um exagero afirmar que nesta situação a indústria nacional se transforma em uma importadora de bens e sua capacidade de agregar valor é brutalmente esmagada, sendo possível apenas a utilização de seus canais de venda para tal (SAMPAIO, 2015). Neste formato existe uma transformação do próprio capital, portanto, é um processo significativamente mais intenso que a quebra de elos tratada anteriormente:

Em outra medida, observa-se um segundo movimento da desindustrialização, acentuando os impactos para o desenvolvimento econômico nacional. Trata-se, por exemplo, da regressão das formas do capital, ou seja, de empresas que eram predominantemente de "capital industrial" e passaram a atuar de forma mais preponderante na órbita mercantil (SAMPAIO, 2015, p. 79)

Para investigar sua possível ocorrência, o indicador utilizado como proxy será o coeficiente de penetração das importações na indústria de transformação, o qual avalia a participação do produto importado no consumo aparente do produto (produção menos exportação mais importação) ${ }^{16}$ de maneira que números mais elevados demonstram um agravamento deste processo. No Gráfico 7, está descrito a evolução desse indicador no período de 2003-2017 a preços constantes:

\section{Gráfico 7: Coeficiente de Penetração das Importações na Indústria de Transformação (Preços Constantes \%)}

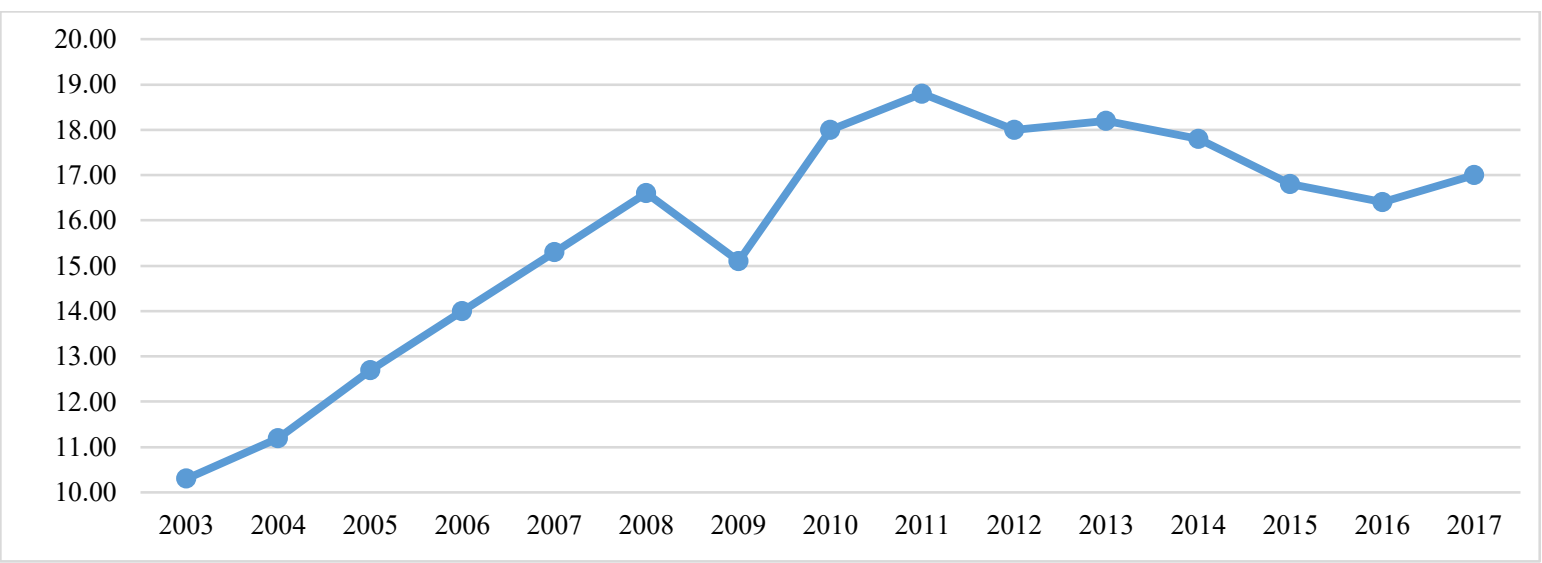

Fonte: CNI, Vários anos. Elaboração Própria

Referenciando-se no Gráfico 7, em relação ao indicador a preços constantes de maneira geral é observado um forte aumento no período desta série, em 2003 o valor era pouco mais de 10\%, chegando em $16,6 \%$ em 2008 , devido ao efeito da crise internacional cai para $15,10 \%$ em 2009 . No entanto, logo no ano seguinte retoma sua trajetória de alta e alcança o valor de aproximadamente 19\% em 2011. Posteriormente, tem relativa queda e em 2017 se apresenta na casa dos 17\%.

Assim como os indicadores da seção anterior, esta evolução denota uma maior dependência externa da indústria nacional para a realização das atividades, mas com uma severidade mais elevada já que aqui não são apenas partes dos componentes que são importados, mas o produto final completo. Esta

\footnotetext{
${ }^{16}$ Este indicador é disponibilizado pela Confederação Nacional da Indústria (CNI)
} 
alteração do indicador de penetração das importações pressupõe um enfraquecimento quase que absoluto de parte da indústria manufatureira brasileira, porque o que ele relativamente demonstra é que algumas unidades industriais se sentiram "desestimuladas" a participar da atividade produtiva. No caso anterior, (da quebra de elos) embora apresentassem aspectos negativos como já demonstrado anteriormente, as unidades conseguiam, mesmo que de maneira limitada, participar de parte da produção e com isso criavam-se a possibilidade do surgimento de progresso técnico dentro dos elos da cadeia ao qual ainda tinham algum acesso. A partir disso, seria possível o aumento de produtividade atingindo um maior grau de competitividade, por exemplo, no mercado externo.

Neste patamar da desindustrialização (de substituição do produto final nacional pelo importado) essa possibilidade é praticamente extinta. Porém, o que se demonstra mais preocupante é a magnitude com que o indicador evoluiu; no período de 2003 a 2015 é observado um aumento de aproximadamente $39 \%$. Outro motivo para esta evolução do indicador, além dos já dos descritos anteriormente, é possível adicionar a financeirização, fenômeno pelo qual o setor financeiro esmaga pela dimensão e domínio os demais setores da economia, obrigando até as empresas não-financeiras a ingressar nesse setor de maneira que os capitalistas que comandam os negócios das unidades industriais ao invés de reinvestirem os lucros obtidos através da atividade produtiva no próprio setor, optam por investir em atividades ligadas ao rentismo, justamente por estas apresentarem lucratividade relativamente elevada e com baixo risco (RÍCUPERO, 2014).

Embora o aumento da magnitude apresentada pelo indicador de penetração das importações seja algo impressionante, talvez pareça uma análise relativamente vaga, por não ter nenhum tipo de comparação. A partir disso, é relevante observar o que aconteceu com as exportações de manufaturas no mesmo período. Para auxiliar na robustez dessa análise podemos considerar os dados do indicador do coeficiente de exportações líquidas também calculado pela CNI, que têm como intuito mostrar a diferença entre as receitas obtidas com as exportações e as despesas com a importação de insumos industriais, ambos medidos em relação ao valor da produção. Se o coeficiente é positivo, a receita com exportação é maior do que os gastos com importações de insumos industriais. A seguir podemos mostrar a evolução deste indicador no mesmo período do gráfico anterior:

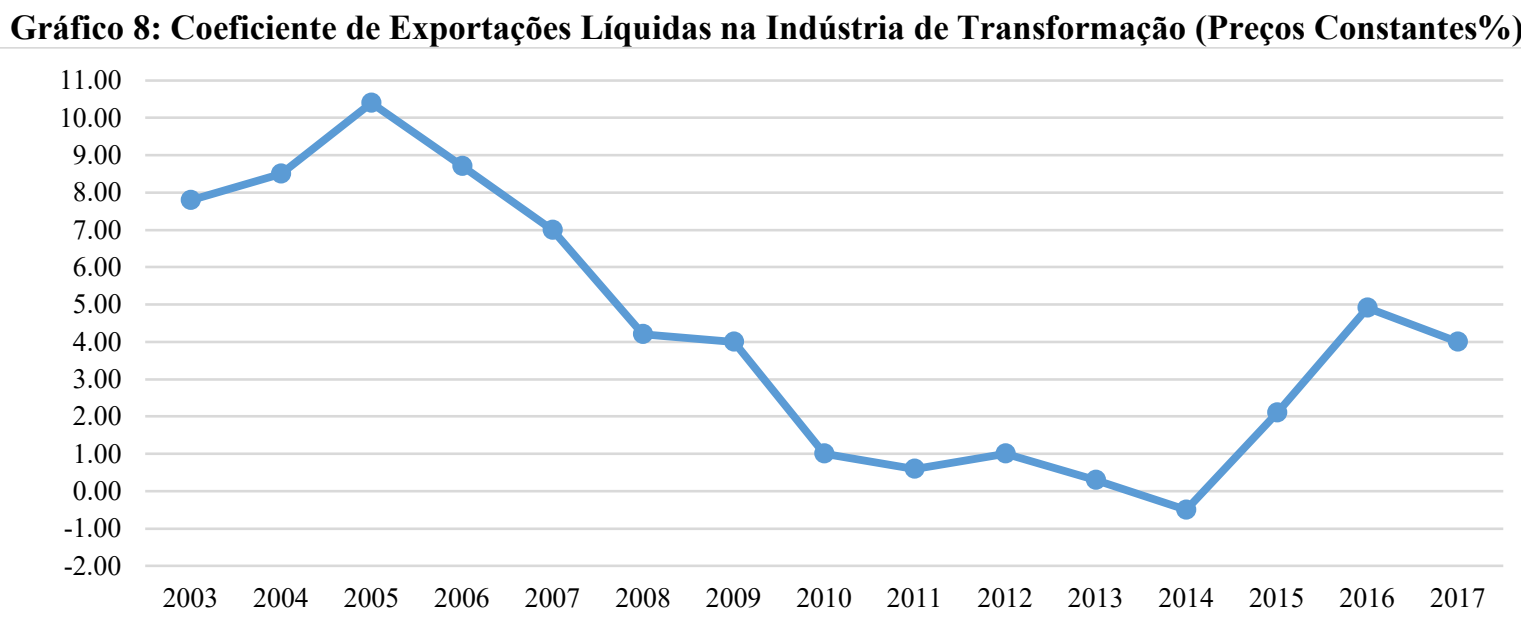

Fonte: CNI, Vários anos. Elaboração Própria

É possível notar um aumento de 2003 até 2005, alcançando o valor de 10,6\%, porém, a partir de 2006 temos uma abrupta queda que perdura até 2014 quando o indicador passa a apresentar um valor negativo $-0,5 \%$, recuperando-se posteriormente, provavelmente devido à forte desvalorização cambial ocorrida a partir de 2015. Sem dúvidas esse indicador reforça a ideia construída até aqui ${ }^{17}$, de que o forte aumento das importações tanto de insumos para a produção quanto de produtos finais não tiveram uma contrapartida nas exportações, muito pelo contrário, parece que na medida em que parte da produção

\footnotetext{
${ }^{17}$ Da seção anterior em conjunto com esta.
} 
passa a ser parcialmente ou totalmente delegada ao exterior, a exportação de manufatura se enfraquece em uma magnitude ainda maior.

Como mencionado de maneira breve, anteriormente, os efeitos são mais graves do que nos formatos anteriores de desindustrialização relativa, porque neste nível, o valor agregado gerado com a produção industrial é drasticamente reduzido, ou seja, o potencial efeito de geração de renda e emprego tem sua magnitude diminuída em um patamar ainda maior que no cenário anterior, isto é, a geração de renda e emprego com a produção é praticamente zero, justamente por ela não existir no sentido produtivo passando a ter caráter mercantil. As unidades industriais nacionais passam a funcionar como "meras revendedoras", devido aos produtos virem praticamente prontos para a comercialização, via importação e somente os canais de vendas nacionais e prestação de assistência são fornecidos pelas indústrias locais.

A balança comercial de produtos manufaturados neste estágio é forçada de maneira negativa e tende a apresentar resultados negativos, criando uma pressão ainda maior na balança de pagamentos devido a fuga de divisas. Um novo efeito que pode ser observado com a desindustrialização neste formato é uma espécie de efeito schumpeteriano às avessas, ou seja, "destruição não-criativa" e de maneira rápida, porque a indústria de manufatura nacional perde quase que em sua totalidade as forças para competir em um cenário global ou abastecimento interno; Em outras palavras, teve-se apenas a destruição mas nada de criação (RICÚPERO, 2014).

Assim é perceptível que a retirada de medidas protecionistas em um país como o Brasil, que historicamente apresenta variáveis macroeconômicas como altas taxas de juros em relação aos seus concorrentes, câmbio e carga tributária em um patamar que afastam investimentos em manufatura (especialmente nos setores de alta tecnologia) acaba contribuindo para a ocorrência dos processo de desindustrialização relativa, tanto no formato de quebra elos, quanto na substituição do produto final nacional pelo importado ${ }^{18}$ (RÍCUPERO, 2014; SAMPAIO, 2015; SARTI E HIRATUKA, 2017; DIEGUES E ROSSI, 2017). Os dados trazidos nesta seção sugerem ao menos, sinais da ocorrência de desindustrialização relativa em sua intensidade de maior grau.

\section{Conclusão}

O objetivo deste presente capítulo foi o de investigar a possível ocorrência do processo de desindustrialização no Brasil através de diversos indicadores. Devido à limitação dos indicadores mais tradicionais, optou-se por utilizar a proposta metodológica que possibilitou analisar um possível processo de desindustrialização por um prisma diferente, permitindo assim identificar o processo em formatos distintos assim como intensidades (severidade) diferenciadas.

Observando e analisando os resultados, assim como a trajetória dos dados apresentados durante o presente capítulo, é possível concluir que existe uma série de sinais que leva a interpretação de que o Brasil passa por um processo de desindustrialização relativa, e isso ocorre nos três formatos previstos pela proposta metodológica, ou seja, os dados permitem inferir que o país passa por um processo de desindustrialização por: $i$ ) aumento do gap tecnológico, $i$ i) redução do conteúdo nacional pelo importado e iii) substituição do produto nacional final pelo importado. O Quadro 1 a seguir ajuda a entender quais foram os resultados gerais descobertos através da proposta metodológica utilizada:

\footnotetext{
${ }^{18}$ Embora Ricúpero se referencie a ambos os formatos de desindustrialização aqui tratados como relativa de "estágios" eles podem ocorrer ao mesmo tempo.
} 
Quadro 1: Resumo dos Resultados dos Indicadores

\begin{tabular}{|c|c|}
\hline Formato & $\begin{array}{c}\text { Indicadores Utilizados } \\
\text { (Principais e Complementares) }^{19}\end{array}$ \\
\hline $\begin{array}{c}\text { Desindustrialização Relativa } \\
\text { por aumento do Gap } \\
\text { Tecnológico }\end{array}$ & GII, Pintec e Outros ${ }^{20}$ \\
\hline $\begin{array}{l}\text { Desindustrialização Relativa } \\
\text { por redução do conteúdo } \\
\text { nacional pelo importado }\end{array}$ & $\begin{array}{c}\text { 1- Coeficiente de Insumos Importados } \\
\text { 2- Relação VTI/VBPI } \\
\text { 1- Saldo da Comercial de Manufaturados, } \\
\text { 2- Estrutura de peso dos setores por categoria de uso, } \\
\text { 3- Evolução do produto industrial da indústria de transformação e de bens } \\
\text { intermediários, }\end{array}$ \\
\hline $\begin{array}{l}\text { Desindustrialização Relativa } \\
\text { por substituição do produto } \\
\text { nacional final pelo importado }\end{array}$ & $\begin{array}{l}\text { 1- Coeficiente de penetração das importações } \\
\text { 1- Coeficiente de exportações } \\
\text { 2- Coeficiente de exportações líquidas }\end{array}$ \\
\hline
\end{tabular}

Fonte: Vários textos. Elaboração Própria

Como se pode observar no quadro acima, foram utilizados diversos indicadores, tanto principais quanto complementares dadas às suas respectivas limitações, é possível concluir que o Brasil apresenta sinais significativos de desindustrialização relativa em seus 3 formatos possíveis listados aqui neste capítulo.

A partir do início dos anos de 1990 foi iniciado o processo de abertura comercial, em conjunto com abertura financeira. Somente esses dois processos (especialmente a abertura comercial) já promoveram dificuldades à indústria nacional devido ao fato de as aberturas terem sido feitas de maneira relativamente desordenas e demasiadamente rápidas. Neste mesmo período, as conduções de políticas macroeconômicas foram estabelecidas na contramão das necessidades da indústria. Ainda neste mesmo período é possível notar a ascensão de novas potencias industriais emergentes como os países asiáticos, o que tornava a competição ainda mais acirrada. Todo este conjunto de fatores internos e externos levou a indústria nacional a ter uma resposta defensiva, ou seja, para ainda permanecer com algum grau de competitividade, parte da produção (principalmente de insumos) foi delegada ao exterior justamente porque estes segmentos não conseguiam mais competir com os produtos internacionais, e o resultado disso foi uma involução da estrutura industrial nacional, sendo este processo foi ainda mais intensificado após a crise de 2008.

O que pode ser constatado de fato foi que esta mudança estrutural industrial acarretou em uma perda de competitividade da manufatura nacional, ocasionando problemas de caráter interno, como menor geração de emprego e renda e externamente configurou uma inserção subordinada nas cadeias globais de valor, marcada pela exportação de produtos considerados commodities e manufatura de baixa intensidade tecnológica. Estes resultados corroboram o que chamamos de quebra elos e que Sarti e Hiratuka (2017 nomearam de especialização regressiva da estrutura industrial nacional. Todos os resultados encontrados pelos autores em conjunto com os indicadores analisados neste trabalho, demonstram que principalmente partir da década de 1990 e depois intensificando-se após a crise de 2008, houve um processo de perda de competitividade da manufatura nacional de maneira que parte do que outrora era produzido nacionalmente foi delegado ao exterior e o distanciamento tecnológico foi se intensificando. A partir disso é possível notar que, em maior ou menor grau, todos os pontos colocados a linha de pensamento ortodoxa parecem ter uma visão relativamente desconectada da realidade brasileira.

\section{Referências Bibliográfica}

AREND, M.; FONSECA, P. C. D. Brasil (1955-2005): 25 anos de catching up, 25 anos de

\footnotetext{
${ }^{19}$ Os indicadores principais (em negrito) são aqueles são utilizados segundo a metodologia proposta por Sampaio (2015), porém foram trazidos outros indicadores que ajudam a reforçar a análise (complementares).

${ }^{20}$ A presença de gap tecnológico pode ser mensurada de várias formas, devido a isso foram usados diversos indicadores trazidos pelo Global Inovation Index, Pintec, Estudos investigando Cathing Up e Falling Behind e outros testes econométricos.
} 
Falling behind. Revista de Economia Política, São Paulo, v. 32, n. 1, p. 33-54, 2012.

CANO, W. (Des)Industrialização e (Sub)Desenvolvimento. Texto apresentado no $2^{\circ}$ Congresso Internacional do Centro Celso Furtado, Centro de Estudos do BNDES, Rio de Janeiro, 18 a 20 de agosto de 2014.

CARNEIRO, R. Impasses do desenvolvimento brasileiro: a questão produtiva. Textos para discussão IE/Unicamp $\mathrm{n}^{\circ}$ 153. Disponível em: <www.eco.unicamp.br>. Acesso em: 20outubro 2018.

CASSIOLATO, J. E.; SZAPIRO, M. LASTRES, H. M. M. Dilemas e perspectivas da política de inovação. In:

Nelson Marconi; Nelson Barbosa; Mauricio Canedo; Laura Carvalho. (Org.). Indústria e Desenvolvimento

Produtivo no Brasil. 1ed.Rio de Janeiro: Elsevier, 2015.

CASSIOLATO; LASTRES, H. M. M. Celso Furtado e os Dilemas da Indústria e Inovação no Brasil. Cadernos do Desenvolvimento, v. 10, p. 188-213, 2015.

CNI. Desempenho do Brasil no índice global de inovação 2011-2017 / Confederação Nacional da Indústria /

Confederação Nacional da Indústria, Serviço Social da Indústria, Serviço Nacional de Aprendizagem Industrial,

Serviço Brasileiro de Apoio às Micro e Pequenas Empresas. -- Brasília: CNI, 2017.

DIEESE. Desindustrialização: conceito e situação no Brasil. Nota Técnica, n. 100, jun 2011.

DIEGUES, A. C.; ROSSI, C. Além da desindustrialização: transformações no padrão de organização e acumulação da indústria em um cenário de 'Doença Brasileira'. In: ENCONTRO NACIONAL DE ECONOMIA POLÍTICA, 21, Anais 2016.

DINIZ, C. Expansão asiática, corrida científica e tecnológica mundial, desindustrialização no Brasil - Belo Horizonte: UFMG/CEDEPLAR, 2017 (Texto para discussão, 565).

DUTTA, S.; LANVIN, B. Global Index Inovation. Cornell University, INSEAD, and the World Intellectual

Property Organization, 2018.

GURRY, F. World Intellectual Property Indicators. Switzerland, 2018.

HIRATUKA, C.; SARTI, F. Transformações na estrutura produtiva global, desindustrialização e

desenvolvimento industrial no Brasil. Revista de Economia Política, v. 37, n. 1 (146), p. 189-207, 2017.

IBGE. Pesquisa Industrial Anual - Empresa. Vários anos. Retirado de: <www.ibge.gov.br>. Acesso em: 25 agosto 2018.

LAVOPA, A.; SZIRMAI, A. Industrialisation in time and space. Viena: Unido, 2015. (Working Paper, 10/2015).

IEDI - INSTITUTO DE ESTUDOS PARA O DESENVOLVIMENTO INDUSTRIAL. Carta IEDI 773. São

Paulo: IEDI: 2017

MARCONI, N.; ROCHA, M. Taxa de câmbio, comércio exterior e desindustrialização precoce: o caso brasileiro. Economia e Sociedade (UNICAMP. Impresso), v. 21, 2012.

MORCEIRO, P. C. Desindustrialização na economia brasileira no período de 2000-2011: abordagens e indicadores. São Paulo: Ed. Unesp/Cultura Acadêmica, 2012.

OREIRO, J.L. Macroeconomia do desenvolvimento: Uma perspectiva keynesiana. 1. ed. - Rio de Janeiro:

LTC, 2016.

OREIRO, J.L.; BASÍLIO, F.; SOUZA, G. J. Acumulação de capital, taxa real de câmbio e catching-up: teoria e evidência para o caso brasileiro. In. FÓRUM DE ECONOMIA DA FGV/EESP, 10., 2013, São Paulo. São Paulo, outubro 2013.

PEREZ, C. Revoluciones Tecnológicas y Capital Financiero: La Dinámica de las Grandes Burbujas,

2004.Financieras y las Épocas de Bonanza. México: Siglo XXI.

RICUPERO, R. Desindustrialização precoce: futuro ou presente do Brasil. São Paulo: Le Monde Diplomatique Brasil. 06 mar 2014. Retirado de: $<$ http://www.diplomatique.org.br/artigo.php?id=1604>. Acessoem 25 out 2018.

SAMPAIO, D. P. Categorias analíticas para o estudo da desindustrialização brasileira: uma sugestão metodológica em múltiplas escalas espaciais. XI Congresso Brasileiro de História Econômica. 12a Conferência Internacional da História de Empresas, Vitória/ES, 2015.

SARTI, F.; LACERDA A. A manufatura brasileira se afunda na crise, 2017. Disponível em:

$<$ https://www.cartacapital.com.br/revista/948/a-manufatura-brasileira-se-afunda-na-crise $>$. Acesso em: 20 nov 2018.

SARTI, F.; HIRATUKA, C. Desempenho recente da indústria brasileira no contexto de mudanças estruturais domésticas e globais. Campinas: Unicamp. IE, abr. 2017. (Texto para Discussão, 290).

TORRES, R. L.; CAVALIERI, H. Uma crítica aos indicadores usuais de desindustrialização no Brasil. Revista de Economia Política (Online), v. 35, 2015. 